\title{
The influence of local brand image and product quality on customer loyalty at PT. Sinar Menara Deli Medan
}

\author{
Ronnie MT.Sirait ${ }^{1 *}$, Theresia Silvia Nainggolan' ${ }^{2}$, Timsa F.Marbun ${ }^{3}$, Remin Bancin $^{4}$, \\ Nike BR Manullang ${ }^{5}$, Nurweni ${ }^{6}$ \\ ${ }_{1,2,3,4,5,6}$ Fakultas Ekonomi Universitas Darma Agung
}

\begin{abstract}
In managing a leading company, it is necessary to pay attention to the level of Local Brand Image and Product Quality as one of the elements that influence the Purchasing Decision. This study aims to determine the effect of local brand image and product quality on purchasing decisions simultaneously. The type of research used is explanatory research with a quantitative approach. The number of samples used in this study were 66 respondents, namely a number of customers at PT. Graha Aluminum Products. The analysis technique used is multiple linear regression analysis with hypothesis testing, namely $\mathrm{F}$ test (simultaneous) and $\mathrm{T}$ test (persial). The result of multiple linear regression $\mathrm{Y}=3,326+0,357 \mathrm{X} 1+0,695 \mathrm{X} 2$, shows that the local brand image variable has a significant effect on purchasing decisions with a value of tcount 3.105> ttable 2.026. Product Quality variable shows the tcount value of 3.105> 2.026, this means that Product Quality has a significant effect on Purchasing Decisions. The result of Fcount is 237.052> Ftable value of 3.25, that there is a significant influence between the variables of Local Brand Image and Product Quality simultaneously affect the Purchase Decision. While the value of the coefficient of determination, it is known that the Adjusted $\mathrm{R}$ Square obtained is 0.924 (92.4\%), which means that the Local Brand Image and Product Quality are able to explain the Purchase Decision which illustrates the influence of other variables for the Purchasing Decision of PT. Graha Aluminum Products. Advice given to the leadership of PT. Graha Aluminum Medan Products to further enhance the Local Brand Image and Product Quality so that Purchase Decisions are higher.
\end{abstract}

Keywords: Local Brand Image, Product Quality, Purchase Decision

*Corresponding author: email: ronnie sirait@yahoo.com

\section{Pengaruh citra merek lokal dan kualitas produk terhadap keputusan pembelian pada PT.Graha Aluminium Produk}

\author{
Ronnie MT.Sirait ${ }^{1 *}$, Theresia Silvia Nainggolan ${ }^{2}$, Timsa F.Marbun ${ }^{3}$, Remin $_{\text {Bancin }}{ }^{4}$, \\ Nike BR Manullang ${ }^{5}$, Nurweni ${ }^{6}$ \\ 1,2,3,4,5,6 Fakultas Ekonomi Universitas Darma Agung
}

\begin{abstract}
Abstrak: Dalam pengelolaan suatu perusahaan pimpinan perlu memperhatikan tingkat Citra Merek Lokal dan Kualitas Produk sebagai salah satu unsur yang mempengaruhi Keputusan Pembelian. Penelitian ini bertujuan untuk mengetahui pengaruh Citra Merek Lokal dan Kualitas Produk terhadap Keputusan Pembelian secara simultan. Jenis penelitian yang digunakan adalah penelitan penjelasan (explanatory research) dengan pendekatan kuantitatif. Jumlah sampel yang digunakan penelitian ini sebanyak 66 responden yaitu sejumlah pelanggan di PT. Graha Aluminium Produk. Teknik analisis yang digunakan adalah analisis regresi linier berganda dengan uji hipotesis, yaitu Uji F (simultan) dan Uji T (persial). Hasil regresi linier berganda $\mathrm{Y}=$ 3,326 + 0,357X1 + 0,695X2, menunjukkan variabel Citra Merek Lokal berpengaruh secara signifikan terhadap Keputusan Pembelian dengan nilai $t_{\text {hitung }}$ 3,105 $>\mathrm{t}_{\text {tabel }}$ 2.026. variabel Kualitas Produk menunjukkan nilai $t_{\text {hitung }} 3,105>2.026$ hal ini berarti Kualitas Produk berpengaruh secara signifikan terhadap Keputusan

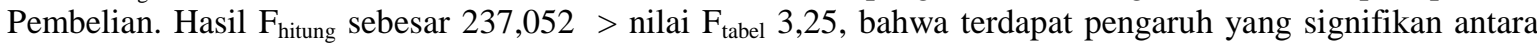
variabel Citra Merek Lokal dan Kualitas Produk secara simultan berpengaruh terhadap Keputusan Pembelian. Sedangkan nilai koefisien determinasi diketahui Adjusted $R$ Square yang diperoleh adalah sebesar 0,924 $(92,4 \%)$, artinya Citra Merek Lokal dan Kualitas Produk mampu menjelaskan Keputusan Pembelian yang menggambarkan pengaruh oleh variabel lain untuk Keputusan Pembelian PT. Graha Aluminium Produk. Saran yang yang diberikan kepada pimpinan PT. Graha Aluminium Produk Medan untuk lebih meningkatkan Citra Merek Lokal dan Kualitas Produk agar Keputusan Pembelian semakin tinggi.

Kata kunci: Citra Merek Lokal, Kualitas Produk, Keputusan Pembelian

*Penulis korespondensi: email: ronnie_sirait@yahoo.com
\end{abstract}




\section{Pendahuluan}

\subsection{Latar Belakang Masalah}

Konsumen saat ini sangatlah kritis dalam memilih suatu produk, keputusan untuk membeli suatu produk sangat dipengaruhi oleh penilaian akan bentuk kualitas produk tersebut. Tuntutan permintaan akan sebuah produk yang semakin berkualitas membuat perusahaan yang bergerak di berbagai bidang usaha berlomba-lomba meningkatkan kualitas produknya demi mempertahankan citra merek produk yang mereka produksi. Merek mempunyai sifat khas, dan sifat khas inilah yang membedakan produk yang satu berbeda dengan produk yang lainnya, walaupun produknya sejenis. Keputusan pembelian pada suatu produk sangat dipengaruh oleh citra merek dan kualitas produk yang di tawarkan. Citra merek (Brand Image ) sangatlah penting untuk meraih pangsa pasar yang diharapkan oleh perusahaan. Saat ini bisnis peralatan rumah tangga di Indonesia sudah menjamur. Di samping itu Pt Graha Aluminium Produk memiliki produk unggul dan kualitas yang baik yang sudah cukup terkenal di kota medan.Jika suatu produk aluminium memiliki citra yang positif dari konsumen, maka peluang terjadinya keputusan pembelian sangat tinggi. Keputusan pembelian sendiri merupakan pemilihan suatu tindakan dari dua atau lebih pilihan alternatif. Seorang konsumen yang hendak melakukan pilihan maka ia harus memiliki pilihan alternatif, jika konsumen tidak memiliki alternatif pilihan maka hal tersebut bukan termasuk dalam situasi konsumen mengambil keputusan (Sumawarman 2014:357). Tak hanya itu saja pengambilan keputusan oleh konsumen untuk melakukan pembelian suatu produk diawali oleh adanya kesadaran atas pemenuhan kebutuhan dan keinginan yang oleh Assael disebut need arousal. Kebanyakan penulis menyatakan tahap ini sebagai tahap menyadari adanya masalah (problem recognition). Selanjutnya jika sudah disadari adanya kebutuhan dan keinginan, maka konsumen akan mencari informasi mengenai keberadaan produk yang diinginkannya. Proses pencarian informasi ini akan dilakukan dengan mengumpulkan semua informasi yang berhubungan dengan produk yang diinginkan. Dari berbagai informasi yang diperoleh konsumen melakukan seleksi atas alternatif-alternatif yang tersedia. Proses seleksi inilah yang disebut sebagai tahap evaluasi informasi. Dengan menggunakan berbagai kriteria yang ada dalam benak konsumen, salah satu merek produk dipilih untuk dibeli.

Konsumen dalam memilih suatu merek produk akan melalui tahap percobaan terlebih dahulu, pada tahap ini seringkali konsumen akan mencoba berbagai merek yang berbeda. Jika dirasakan merek tersebut cocok dan memenuhi apa yang diharapkan dari produk sejenis, maka konsumen akan terus mencari merek tersebut. Brand atau merek adalah nama, istilah, tanda, simbol desain ataupun kombinasinya yang mengidentifikasi suatu produk atau jasa yang dihasilkan oleh suatu perusahaan (Durianto dan Budiman, 2004).

Kualitas memiliki arti yang sangat penting dalam keputusan pembelian konsumen. Apabila kualitas produk yang dihasilkan baik maka konsumen cenderung akan melakukan pembelian ulang terhadap suatu produk. Sebaliknya jika kualitas produk tidak sesuai dengan harapan, maka konsumen akan mengalihkan pembeliannya pada produk sejenis lainnya. Untuk mencapai kualitas produk yang diinginkan maka diperlukan suatu standarisasi kualitas. Cara ini dimaksudkan untuk menjaga agar produk yang dihasilkan dapat memenuhi standar yang telah ditetapkan sehingga konsumen tidak akan kehilangan kepercayaan terhadap produk yang bersangkutan. Definisi dari kualitas produk adalah kemampuan sebuah produk dalam memperagakan fungsiya, hal ini termasuk keseluruhan durabilitas, reliabilitas, ketepatan, kemudahan pengoperasian, dan reparasi produk, juga atribut produk lainnya (Kotler \& Amstrong 2012 : 283). Suatu produk dikataka kebutuhan dan keinginan pembeli. Kualitas ditentukan oleh pelanggan, dan pengalaman mereka terhadap produk atau jasa.

Graha Aluminium Produk merupakan salah satu perusahaan produsen peralatan Rumah tangga seperti Rak piring merk Excellent terbesar di kota medan, sangat memahami pentingnya kegunaan rak piring dalam peralatan rumah tangga. Selain kualitas produk yang baik, kenyamanan dan 
keamanan sangat diperlukan dalam kebutuhan peralatan rumah tangga, dan merk excellent GAP yang dapat mewujudkan hal itu. Graha aluminium produk menawarkan rak piring yang kokoh dan tahan karat saat digunakan karena bahan aluminium yang digunakan berkualitas.

Berdasarkan Uraian di atas penulis tertarik untuk meneliti, menulis lebih lanjut dan menuangkannya dalam bentuk skripsi dengan judul " Pengaruh Citra Merek lokal dan Kualitas Produk terhadap Keputusan Pembelian Pada PT. Graha Aluminium Produk di Kota Medan”.

\subsection{Batasan Masalah}

Untuk memfokuskan dan memperkecil batasan masalah, agar tidak terjadi hal-hal yang tidak diinginkan dalam pembahasan, maka peneliti membatasi masalah haya pada "Citra Merek Lokal, Kualitas Produk dan Keputusan Pembelian Pada PT. Graha Aluminium Produk di Medan"

\subsection{Rumusan Masalah}

Berdasarkan masalah yang diuraikan, maka yang menjadi rumusan masalah dalam penelitian ini adalah berikut :

1. Apakah kesesuaian Citra Merek Lokal berpengaruh signifikan terhadap Keputusan Pembelian pada PT. Graha Aluminium Produk Medan?

2. Apakah Kualitas Produk berpengaruh signifikan terhadap Keputusan Pembelian Rak pada PT. Graha Aluminium Produk Medan?

3. Apakah Citra Merek Lokal dan Kualitas Produk secara bersama-sama berpengaruh signifikan terhadap Keputusan Pembelian pada PT. Graha Aluminium Produk Medan?

\subsection{Tujuan Penelitian}

Berdasarkan rumusan masalah di atas maka, penulis menentukan tujuan penelitian, adapun tujuan penelitian ini adalah sebagai berikut :

1. Untuk menambah wawasan penulis Pengaruh Citra Merek Lokal dan Kualitas Produk terhadap Keputusan Pembelian pada PT. Graha Aluminium Produk di Kota Medan

2. Sebagai bahan perbandingan bagi pimpinan perusahaan tentang Pengaruh Citra Merek Lokal dan Kualitas Produk terhadap Keputusan Pembelian pada PT. Graha Aluminium Produk di Kota Medan

3. Sebagai bahan refernsi bagi peneliti selanjutnya mengenai Pengaruh Citra Merek Lokal dan Kualitas Produk terhadap Keputusan Pembelian pada PT. Graha Aluminium Produk di Kota Medan

\subsection{Manfaat Penelitian}

\section{Manfaat Teoritis}

Hasil penelitian ini diharapkan dapat memberikan bahan yang bermanfaat bagi pengembang ilmu penelitian dan untuk menambah wawasan berpikir serta menambah pengetahuan penulis dalam bidang pemasaran khususnya mengenai Pengaruh Citra Merek Lokal dan Kualitas Produk terhadap Keputusan Pembelian pada PT. Graha Aluminium Produk di Kota Medan

2. Manfaat Praktis

a. Dengan penelitian ini diharapkan dapat berguna bagi penulis sendiri dalam memperluas dan memperdalam wawasan dalam bidang pemasaran termasuk langkah langkah dalam meningkatkan Citra Merek Lokal dan Kualitas Produk terhadap Keputusan Pembelian didalam suatu perusahaan.

b. Dengan penelitian ini diharapkan dapat memberikan masukan kepada pihak pimpinan perusahaan dibidang pemasaran khususnya dalam meningkatkan Citra Merek Lokal dan Kualitas Produk terhadap Keputusan Pembelian.

c. Hasil penelitian ini diharapkan dapat memberikan informasi kepada pihak yang ingin meneliti pada permasalahan yang sama pada masa yang akan datang. . 


\section{Uraian Teoritis}

\subsection{Landasan Teori}

\section{Pengertian Loyalitas Pelanggan}

Konsumen memutuskan membeli suatu produk tentunya memilih yang citra mereknya positif karena jikalau citra merek positif berarti konsumen sudah dapat percaya penuh terhadap produk tersebut. Menurut Kotler (2012 : 276), "menyatakan citra merek adalah persepsi dan keyakinan yang dipegang oleh konsumen, seperti tercermin dalam asosiasi yang terjadi dalam memori konsumen" Menurut Tjiptono (2011 : 112) , "Citra merek yakni deskripsi tentang asosiasi dan keyakinan konsumen terhadap merek tertentu". Sejumlah teknik kuantitatif dan kualitatif telah dikembangkan untuk membantu mengungkap persepsi dan asosiasi konsumen terhadap sebuah merek tertentu.

\section{Indikator Citra Merek}

Indikator Citra Merek Adapun indikator citra merek menurut Ratri (2012) yaitu sebagai berikut:

a. Atribut produk (product attribute), merupakan hal-hal yang berkaitan dengan merek tersebut sendiri, seperti kemasan, rasa, harga, dan lain-lain.

b. Keuntungan konsumen (consumer benefits), merupakan kegunaan produk dari merek tersebut.

c. Kepribadian merek (brand personality), merupakan asosiasi yang mengenai kepribadian sebuah merek apabila merek tersebut adalah manusia.

\section{Pengertian Kualitas Produk}

Menurut Ariyoto (2011:92) kualitas adalah "totalitas bentuk dan karakteristik barang yang menunjukkan kemampuannya untuk memuaskan kebutuhan dan keinginan dari konsumen". Kualitas produk merupakan suatu hal yang penting dalam menentukan pemilihan suatu produk oleh konsumen. Produk yang ditawarkan haruslah suatu produk yang benar-benar teruji dengan baik mengenai kualitasnya.Konsumen akan lebih menyukai dan memilih produk yang mempunyai kualitas lebih baik bila dibandingkan dengan produk lain sejenis yang dapat memenuhi kebutuhan dan keinginannya

\section{Indikator Kualitas Produk}

Indikator kualitas produk menurut Tjiptono (2010:101) adalah:

a. Performance (kinerja), yang berhubungan dengan berbagai karakteristik operasi dasar dari sebuah produk.

b. Durability (daya tahan), yang berarti berapa lama atau umur produk yang bersangkutan bertahan sebelum produk tersebut harus diganti. Semakin besar frekuensi pemakaian konsumen terhadap produk maka semakinbesar pula daya produk.

c. Conformance to specification (kesesuaian dengan spesifikasi), yaitu sejauh mana karakteristik operasi dasar dari sebuah produk memenuhi spesifikasi tertentu dari konsumen atau tidak ditemukannya cacat pada produk.

d. Features (fitur), adalah karakteristik produk yang dirancang untuk menyempurnakan fungsi produk atau menambah ketertarikan konsumen terhadap produk.

e. Reliability (reliabilitas), adalah probabilitas bahwa produk akan bekerja dengan memuaskan atau tidak dalam periode waktu tertentu. Semakin kecil kemungkinan terjadinya kerusakan maka produk tersebut dapat diandalkan.

\section{Pengertian Keputusan Pembelian}

Machfoedz (2011:40) mengidentifikasikan bahwa "Pengambilan keputusan mempunyai arti penting bagi maju mundurnya suatu perusahaan, terutama karena masa depan suatu organisasi banyak ditentukan oleh pengambilan keputusan sekarang". Pentingnya pengambilan keputusan dilihat dari segi kekuasaan untuk membuat keputusan, yaitu apakah mengikuti pola sentralisasi atau desentralisasi. Pengambilan keputusan selain dilihat dari segi kekuasaan juga dilihat dari segi kehadirannya, yaitu tanpa adanya teori pengambilan keputusan dministratif, kita tidak dapat 
mengerti, apakah meramalkan tindakan-tindakan manajemen sehingga kita tidak dapat menyempurnakan efektivitas manajemen.

\subsection{Penelitian Terdahulu}

Penelitian-penelitian terdahulu tentang pengaruh citra merek lokal, kualitas produk, desain terhadap keputusan pembelian yang telah banyak dilakukan. Penelitian-penelitian sebelumnya yang berhubungan dengan penelitian ini dapat dilihat pada tabel berikut :

Siti Nurhayati (2017), dengan judul Pengaruh citra merek, harga dan promosi terhadap keputusan pembelian handphone Samsung di Yogyakarta, hasil penelitian menyatakan bahwa Citra merek, harga, promosi ada pada klasifikaasi tinggi sebesar $72 \%$ yang mempengaruhi keputusan pembelian.

Suri Amilia Dan M.Oloan Asmara Nst (2017), judul penelitian Pengaruh Citra Merek, Harga, dan Kualitas Produk terhadap Keputusan Pembelian Handphone Merek Xiaomi di Kota Langsa, Citra Merek, Harga, dan Kualitas Produk, berpengaruh positif signifikan terhadap keputusan pembelian. Handphone Merek Xiaomi di Kota Langsa.

Sunarto (2015), dengan judul Pengaruh kualitas produk terhadap keputusan pembelian pada toko kerajinan kulit kartika magetan. Hasil penelitian yaitu : Kualitas produk berpengaruh positif signifikan keputusan pembelian. pada toko kerajinan kulit kartika magetan

\subsection{Kerangka Pemikiran}

Kerangka pemikiran dalam penelitian ini merupakan interprestasi dari pengaruh kualitas produk, desain dan diferensiasi produk terhadap loyalitas pelanggan.

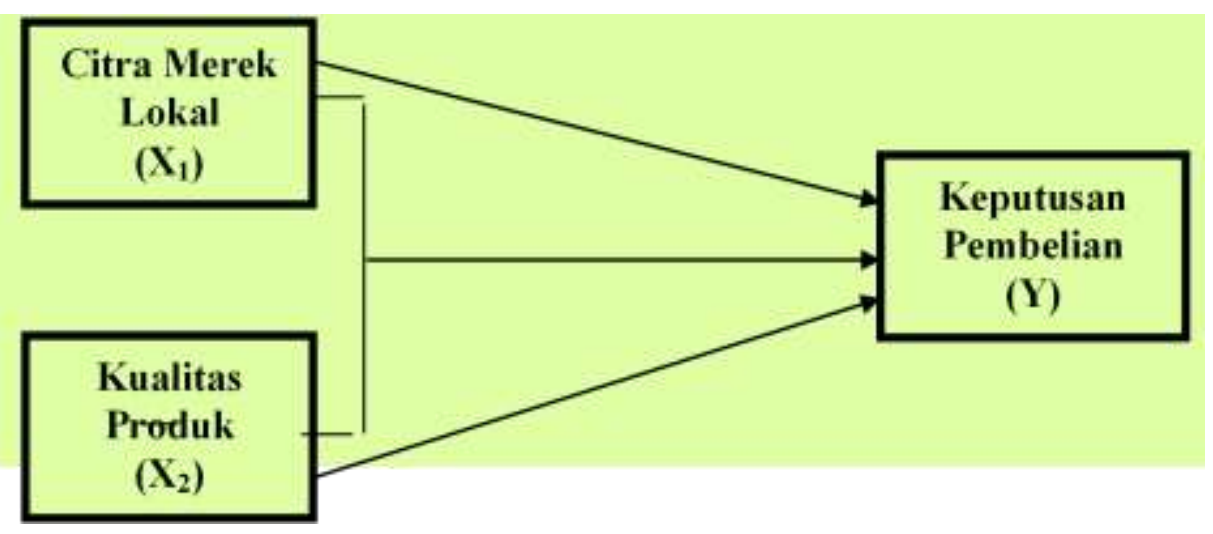

Sumber : Data diolah oleh penulis 2020

Gambar 1 : Kerangka Pemikiran

\subsection{Hipotesis}

Menurut Sugiyono (2010:93), hipotesis merupakan jawaban sementara terhadap rumusan masalah penelitian, dimana rumusan masalah penelitian telah dinyatakan dalam bentuk kalimat pernyataan. Hipotesis merupakan suatu jawaban yang bersifat sementara terhadap permasalahan penelitian, sampai terbukti melalui data yang terkumpul. Dikatakan sementara karena jawaban yang diberikan baru didasarkan pada teori yang relevan, belum didasarkan pada fakta-fakta empiris yang diperoleh melalui pengumpulan data. Jadi hipotesis juga dapat dinyatakan sebagai jawaban teoritis terhadap rumusan masalah penelitian dan belum ada jawaban empiris. Penolakan dan penerimaan hipotesis tergantung pada hasil penyelidikan terhadap fakta-fakta. Dengan demikian, hipotesis adalah suatu teori sementara yang kebenarannya masih perlu diuji.

Berdasarkan masalah diatas, dapat disusun hipotesis penelitian yaitu:

1. Citra Merek Lokal berpengaruh terhadap keputusan pembelian pada PT. Graha Aluminium Produk di Kota Medan. 
2. Kualitas Produk berpengaruh terhadap keputusan pembelian pada PT. Graha Aluminium Produk di Kota Medan.

3. Citra Merek Lokal dan Kualitas Produk berpengaruh secara simultan terhadap keputusan pembelian pada PT. Graha Aluminium Produk di Kota Medan.

\section{Metode Penelitian}

\subsection{Lokasi Dan Waktu Penelitian}

Penelitian ini dilaksanakan pada PT.Graha Aluminium Produk yang beralamat di J1. Kpten Sumarsono, Komp. Graha Metropolitan Ruko Mall Blok G. No. 32 A, 32B, 33 Medan. Waktu penelitian dilakukan oleh mulai bulan April 2020 sampai bulan Oktober 2020.

\subsection{Populasi dan Sampel}

\section{Populasi}

Menurut Sugiyono (2012:115), populasi adalah wilayah generalisasi yang terdiri atas: obyek/subyek yang mempunyai kualitas dan karakteristik tertentu yang di tetapkan oleh peneliti untuk di pelajari dan kemudian di tarik kesimpulannya. Populasi yang akan diambil oleh peneliti dalam penelitian ini adalah sejumlah pelanggan di PT. Graha Aluminium Produk, yaitu berjumlah 66 orang.

\section{Sampel}

Menurut Sugiyono (2016:56), pengertian sampel adalah sebagian jumlah dan karakteristik yang dimiliki oleh populasi tersebut. Bila populasi besar, maka peneliti tidak mungkin mempelajari semua yang ada pada populasi, misalnya karena keterbatasan dana, waktu, dan tenaga, maka peneliti dapat menggunakan sampel yang diambil dari populasi tersebut. Untuk itu, sampel yang diambil dari populasi harus betul-betul mewakili. Dengan jumlah populasi yang sedikit maka sampel pada penelitian ini adalah metode sampel jenuh, dimana semua populasi dijadikan sebagai sampel. Jumlah sampel yang digunakan adalah sebanyak 66 responden.

\section{Hasil Penelitian}

PT. Graha Aluminium Produk merupakan sebuah perusahaan Home Industri yang berada di Jl. Kapten Sumarsono, Graha metropolitan Rukomall Blok 32 B C, 33 Medan Helvetia. PT. Graha Aluminium Produk berdiri pada tahun 2014 oleh tiga orang pengusaha yang masih memiliki ikatan saudara, dengan kata lain PT. Graha Aluminium Produk didirikan dengan alas an untuk mempereratkatan persaudaraan dan memberikan lapangan pekerjaan bagi warga sekitar kota medan. PT. Graha Aluminium Produk Ini merupakan perusahaan yang bergerak di bidang pembuatandan distributor alat rumah tangga yang berbahan Aluminium yang diberi merk GAP Excellent. Saat ini PT. Graha ALuminium Produk sudah memasarkan produk dan sudah memiliki banyak customer yang loyall, hingga saat ini PT. Graha Aluminium produk masih menerima setiap toko yang ingin bekerja sama dalam penyediaan pruduk peralatan rumah tangga. PT. Graha Aluminum Produk juga menerima layanan custom barang sesuai dengan keinginan konsumen. Adapun area pasar PT. Graha Aluminum Produk adalah Kota Medan, Binjai, Tebing tinggi, Seirampah, Aceh, Berastagi, Kabanjahe dan lain-lain.

\section{Pembahasan Hasil Penelitian}

Pembahasan dalam penelitian ini menjelaskan mengenai Pengaruh Citra Merek lokal dan Kualitas Produk terhadap Keputusan Pembelian Pada PT. Graha Aluminium Produk di Kota Medan. Hasil 
penelitian menunjukkan bahwa variabel bebas yaitu Citra Merek lokal dan Kualitas Produk merupakan variabel yang berpengaruh terhadap variabel terikat yaitu Keputusan Pembelian. Pembahasannya adalah sebagai berikut:

Berdasarkan hasil persamaan regresi $\left.\mathrm{Y}=3,326+0,357 \mathrm{X}_{1}+0,695 \mathrm{X}_{2}\right) \mathrm{a}=3,326$ berarti bahwa nilai konstanta, ketika motivasi dan komitmen kerja konstan, maka nilai Keputusan Pembelian 3,326. $\mathrm{b}_{1}=$ Koefisien regresi Citra Merek Lokal sebesar 0,357 menyatakan bahwa apabila Citra Merek Lokal meningkat sebesar

satu satuan, maka Keputusan Pembelian akan meningkat sebesar 0,357 satuan. $b_{2}=$ Koefisien regresi Kualitas Produk sebesar 0,695 menyatakan bahwa apabila Kualitas Produk meningkat sebesar satu satuan, maka Keputusan Pembelian meningkat sebesar 0,695 satuan. Jadi, Citra Merek lokal dan Kualitas Produk memiliki pengaruh positif terhadap Keputusan Pembelian.

Hasil pengujian uji t (parsial) seperti yang terlihat pada tabel 4.14, menunjukkan nilai probabilitas atau nilai signifikan sebesar 0,004 antara variabel Citra Merek Lokal (X1) t-hitung 3,105 > 1,686 ttabel dan Kualitas Produk (X2) $t_{\text {hitung }}$ 7,042>1,686 $t_{\text {tabel }}$. Hal ini menunjukkan bahwa Citra Merek Lokal dan Kualitas Produk berpengaruh signifikan terhadap Keputusan Pembelian pada PT. Graha Aluminium Produk di Kota Medan.

Hasil pengujian uji t (parsial) antara variabel Kualitas Produk terhadap variabel Keputusan Pembelian menunjukkan nilai $t_{\text {hitung }}$ 7,042 lebih besar dibandingkan $t_{\text {tabel }}$ 1,686 dan nilai sig 0,000 yang jauh lebih kecil dari 0,05. Sehingga, dapat disimpulkan bahwa berpengaruh signifikan antara Kualitas Produk dengan Keputusan Pembelian pada PT. Graha Aluminium Produk di Kota Medan.. Jadi berdasarkan hasil pengujian secara parsial bahwa variabel yang paling berpengaruh terhadap Keputusan Pembelian pada PT. Graha Aluminium Produk di Kota Medan. adalah Kualitas Produk dengan $t_{\text {hitung }}$ sebesar 7,042 dibandingkan dengan $t_{\text {hitung }}$ Citra Merek Lokal yang memperoleh nilai sebesar 3,105.

Nilai $F_{\text {hitung }}$ sebesar 237,052 lebih besar dibandingkan nilai $F_{\text {tabel }}$ 2,87 dengan nilai signifikansi (sig.) 0,000. Karena nilai signifikansi (sig.) jauh lebih kecil dari 0,05 maka model regresi dapat dikatakan bahwa motivasi dan Kulitas Produk, secara bersama-sama atau secara simultan berpengaruh signifikan terhadap Keputusan Pembelian pada PT. Graha Aluminium Produk.

Nilai koefisien determinasi untuk variabel bebas lebih dari dua digunakan Adjusted R Square. Nilai Adjusted $R$ Square yang diperoleh sebesar 0,924. Hal ini berarti bahwa variasi dari Keputusan Pembelian dipengaruhi oleh Citra Merek Lokal, dan Kualitas Produk sebesar 92,4\% dan sisanya sebesar 7,6\% dipengaruhi faktor-faktor lain yang tidak dimasukkan dalam penelitian ini.

Hasil dari penelitian terdahulu adalah sebagai berikut :

Siti Nurhayati (2017), dengan judul Pengaruh citra merek, harga dan promosi terhadap keputusan pembelian handphone Samsung di Yogyakarta. Hasil Penelitian menyatakan bahwa Citra merek, harga, promosi ada pada klasifikaasi tinggi sebesar $72 \%$ yang mempengaruhi keputusan pembelian.

Suri Amilia Dan M.Oloan Asmara Nst (2017), dengan judul Pengaruh Citra Merek, Harga, dan Kualitas Produk terhadap Keputusan Pembelian Handphone Merek Xiaomi di Kota Langsa. Citra Merek, Harga, dan Kualitas Produk, berpengaruh positif signifikan terhadap keputusan pembelian. Handphone Merek Xiaomi di Kota Langsa.

Sunarto (2015), dengan Judul Pengaruh kualitas produk terhadap keputusan pembelian pada toko kerajinan kulit kartika magetan. Kualitas produk berpengaruh positif signifikan keputusan pembelian. pada toko kerajinan kulit kartika magetan. 


\section{Penutup}

Berdasarkan hasil penelitian dan pembahasan yang dilakukan oleh penulis mengenai Pengaruh Citra Merek Lokal dan Kualitas Produk terhadap Keputusan Pembelian Pada PT. Graha Aluminium Produk di Kota Medan, maka penulis memberikan kesimpulan sebagai berikut :

1. Hasil pengujian hipotesis dapat disimpulkan sebagai berikut : $Y=3,326+0,357 X_{1}+0,695 X_{2}$, dari persamaan regresi diinterprestasikan beberapa hal antara lain : Nilai Konstanta sebesar 3,326 menjelaskan bahwa tanpa adanya Citra Merek Lokal $\left(\mathrm{X}_{1}\right)$ sebesar 0,357 dan Kualitas Produk $\left(\mathrm{X}^{2}\right)$ maka perolehan nilai Keputusan Pembelian sebesar 0,695 artinya jika Citra Merek lokal dan Kualitas Produk samakin tinggi maka Keputusan Pembelian juga semakin tinggi.

2. Citra Merek Lokal $\left(\mathrm{X}_{1}\right)$ berpengaruh terhadap Keputusan Pembelian (Y) pada PT. Graha Aluminium Produk di Kota Medan.

3. Kualitas Produk $\left(\mathrm{X}_{2}\right)$ berpengaruh terhadap Keputusan Pembelian (Y) pada PT. Graha Aluminium Produk di Kota Medan

4. Citra Merek Lokal $\left(\mathrm{X}_{1}\right)$ dan Kualitas Produk $\left(\mathrm{X}_{2}\right)$ secara simultan berpengaruh terhadap Keputusan Pembelian (Y) pada PT. Graha Aluminium Produk di Kota Medan.

5. Berdasarkan hasil pengujian determinasi $\left(\mathrm{R}^{2}\right)$ Nilai Adjusted $R$ Square yang diperoleh sebesar 0,924. Hal ini berarti bahwa variasi dari Keputusan Pembelian dipengaruhi oleh Citra Merek Lokal dan Kualitas Produk sebesar 92,4\% dan sisanya sebesar 7,6\% dipengaruhi variabel lain yang tidak diteliti dalam penelitian ini.

\section{Kepustakaan}

Ariani, Dorothea Wahyu, 2013. Manajemen Kualitas Pendekatan Sisi Kualitatif. Ghalia Indonesia: Jakarta.

Budiharja, Gigih Erlik. \& Riyono. 2016. Pengaruh Kualitas Produk, Harga, Promosi dan Brand Image Terhadap Keputusan Pembelian. Jurnal Stie Semarang. Vol 8, No 2.

Fandy, Tjiptono. 2011. Service Management Mewujudkan Layanan Prima. Edisi 2. $\quad$ Yogyakarta: Andi.

Ghozali, Imam. 2016. Aplikasi Analisis Multivariete dengan pogram SPSS 23. Ed. 8, Semarang: Badan Penerbit Universitas Ponogoro.

\& Kevin Lane Keller. 2012, Manajemen Pemasaran Edisi 13 Jilid 1. Penerbit Erlangga: Jakarta.

dan Keller, 2012, Manajemen Pemasaran, Jilid I, Edisi Kedua belas, PT. Indeks, Jakarta.

; Armstrong, Garry, 2010. Prinsip-prinsip Pemasaran, Jilid 1, Erlangga, Jakarta

Nst. M.Oloan asmara. \& Suri Amalia. 2017. Pengaruh Citra Merek, Harga, dan Kualitas Produk terhadap Keputusan Pembelian. Jurnal Manajemen \& Keuangan. Vol.6, No.1.

Nurhayati, Siti. 2017. Pngaruh Citra Merek, Harga dan Promosi Terhadap Keputusan Pembelian. JMBA. Vol. IV, No. 2.

Schiffman \& Kanuk. 2004. Perilaku Konsumen (edisi 7). Jakarta: Prentice Hall.

Sugiyono. 2012. Metode Penelitian Bisnis. Cetakan Keenambelas. Bandung: Alfabeta.

Sujarweni, Wiratna. 2014. Metodologi Penelitian. Cetakan Pertama. 